\title{
Risk Management Committee Attributes and Firm Performance
}

\author{
Basiru Salisu Kallamu \\ Putra Business School, University Putra Malaysia \\ 43400 UPM Serdang, Selangor DarulEhsan. Malaysia \\ E-mail: bkallamu001@yahoo.com
}

Received: Nov. 17, 2015

Accepted: Dec. 5, 2015

Published: Dec. 10, 2015

doi:10.5296/ifb.v2i2.8580

URL: http://dx.doi.org/10.5296/ifb.v2i2.8580

\begin{abstract}
We investigate the impact of risk management committee attributes on firm performance for a sample of 37 finance companies listed on the Malaysian stock exchange covering period from 2007 financial year to 2011. The result indicates that a committee composed of majority independent directors positively enhances firm market valuation and negatively affects accounting returns. Independent committee chair was found to positively enhance accounting returns while prior executive experience of directors enhances both accounting returns and market valuation of the companies. Lastly, presence of executive on RMC shows a significant negative relationship with ROA. The result supports agency theory which suggests that independent directors are in a better position to monitor the executive and protect the interest of the various stakeholders. In addition, the result suggests that regulatory agencies should consider recommending finance companies to have directors with prior executive experience to serve on risk management committee.
\end{abstract}

Keywords: corporate governance, risk management committee, independent directors, independent committee chair, expertise and experience, executive membership 


\section{Introduction}

Financial institution and economies in the world have felt the impact of the recent global financial crisis in different ways and in different magnitude (Atik, 2009). While some of the companies had to file for bankruptcy others were faced with low performance and in some case the need to downsize their operations. In terms of the impact on the economies, some government had to intervene with several rescue packages while others had to cope with reduction in exports, foreign direct investment and rising unemployment (Khoon \& Mah-Hui, 2010). The impact of the crisis has re-emphasized the significance of good corporate governance practices in finance companies. The crisis that started in 2007 led to bankruptcies of many financial institutions in the west (Becht, Bolton, \& Roell, 2011). The authorities had to intervene with various rescue packages to save the troubled companies. This led to the injection of the public funds into such institutions to prevent total collapse of the system. In other places the governments had to nationalize the finance companies and force a change in the board of the finance companies.

Furthermore, authorities instituted committees to look into remote and immediate factors that triggered the problem and to suggest ways to overcome the problem and prevent future occurrence. Some recommendations of these committees include the enhancement of internal control over risk and the alignment of remuneration with risk. Different reasons have been suggested as the possible causes of the recent financial crisis. The complex nature of the financial inventions, the change in focus of finance companies, US subprime crisis and US government policy on the provision of housing for its citizens, deposit insurance, government guarantee, excessive risk taking and the compensation plan that is aligned with short-term company performance (Moosa, 2008).

The Asian financial crisis of 1997-1998, the corporate scandals in different parts of the world and the recent financial crisis has affected the performance of finance companies and motivated the research and interest in corporate governance of such companies. These corporate scandals and current financial crisis affected big firms such as Enron and WorldCom, Parmalat, Bear Stearns, Citigroup, Lehman brothers and Dexia (Becht et al., 2011) in the west, Transmile, Megan Media and Oilcorp in Malaysia (Zulkifli \& Abdulsamad, 2007).

The board of directors was a major contributing factor to the crisis due to poor monitoring by its monitoring subcommittees especially risk management and remuneration committee which enabled the management to take excessive risk and compensation plan that was not aligned with long-term performance (Kashyap, Rajan, \& Stein, 2008). Various components of corporate governance have their own share of the blame for the occurrence of the crisis and failures. The board of directors was accused of negligence in performance of their monitoring functions (the magnitude of losses incurred by the companies during the crisis is an evidence of non-performance of the monitoring function by the board), while management has been blamed for taking excessive risk which was possible due to the poor monitoring of the risks of the corporations by the board (Erkens, Hung, \& Matos, 2012). The emphasis on compensation plan linked to short term performance have contributed to the occurrence of the 
corporate failures and the financial crisis by encouraging management to take risky investment which will enable them to be entitled to the short term rewards (Kashyap et al., 2008). This excessive risk taken by some of the banks resulted into the banks sustaining huge losses.

Another contributing factor to the recent financial crisis was the risk management committee that was saddled with the responsibility of managing the risk of the companies. Inadequate monitoring by subcommittee was one of the issues that contributed to corporate various scandal sand the recent global financial crisis which indicates the weakness in the corporate governance mechanism in the companies (Solomon, 2007; Barney, 2009; Mohamad \& Sulong, 2010; Erkens et al., 2012). The risk management committee in some of the affected companies was found to have been negligent in monitoring risk of the companies (Kashyap et al., 2008). Due to the special nature of the assets of finance companies, it is difficult for outsiders without the required expertize such as independent directors and individual investors to ascertain the actual risk associated with assets of the companies (Erkens et al., 2009).

This is why finance companies have separate risk management committee composed of directors with the required skills to monitor risks facing companies and ensure safeguards put in place to mitigate the risks are adequate. Thus, poor monitoring of the risks of the various companies led to some of the management taking high risk that resulted into the companies incurring significant losses that affected their overall performance. The impacts of the high risks on performance result in removing members of the risk management committee in some of the companies. In other words, where a company incurs a loss that is perceived to result from high risk, there is possibility of changing members of the risk management committee. If on the other hand the loss is seen to result from poor management or poor decision by the management, there may be no change in risk management committee membership since the board would have replaced the CEO.

According to Ghazali (2010) the Asian financial crisis of 1997/1998, the corporate scandals that occurred in some countries/companies and the financial crisis necessitated the move to enhance the corporate governance practice by companies in Malaysia. The different financial crisis and scandals affected the confidence of the investors in capital market. The move was started with the setting up of a finance committee on corporate governance to deal with the issue of establishing codes and principles to guide the companies. Among the recommendations of the committee was the introduction of the Malaysian codes on corporate governance. The finance committee also established the Malaysian institute of corporate governance which operates as a nonprofit public company limited by guarantee. This move was aimed at restoring the confidence of the investors in capital market. Compliance with the codes developed from this initiative was initially voluntary but later made mandatory by the revised listing requirements of the Bursa Malaysia.

The finance sector contributes significantly to the GDP which is the second highest after manufacturing, trade and service sector and there is significant investments of the government in the sector. In addition, the finance sector serves as a channel for the 
implementation of the government macroeconomic policies and other economic programmes such as the National economic policy 1971 (Kim \& Rasiah, 2010). This justifies the emphasis on the good governance of finance companies by the government. Hence, the study of the relationship between risk management committees attributes and performance of finance companies is significant because it has highlighted the characteristics of the subcommittees that enhance the effective monitoring of the various aspects of the functions of the committee. Furthermore, the study has shown how the various forms of interaction between risk management subcommittee and other subcommittees will enhance performance. Thus, this study examines the features of risk management subcommittee which have influence on the performance of finance companies in Malaysia.

Although risk management committee performances vital role in monitoring of risks especially in finance companies, few studies have been carried out on risk management committee (Liebenberg \& Hoyt, 2003; Beasley, Clune, \& Hermanson, 2005; Subramaniam, McManus, \& Zhang, 2009) especially in Malaysia (Yatim, 2009; Ng et al., 2013) and the studies carried out on Malaysian companies focused on factors that determine the establishment of RMC (Yatim, 2009) and on RMC in insurance segment of the finance sector (Ng et al., 2013). Therefore, the paucity of research on the RMC motivates the current study to examine the impact of certain attributes of the RMC on the performance of finance companies. Specifically the paper examines the impact of committee composition, independent chair, expertise and experience of the committee members, executive membership of the committee and interlock of directors on RMC and RC and NC. A RMC with more independent directors, independent chair, expert directors and interlock of directors on subcommittees is likely to enhance monitoring role of the RMC and reduce risks in finance companies thereby enhancing performance. Despite the important role board subcommittees' play and the impact of their interaction on their performance, few studies have examined the impact of such interactions among subcommittees (Carcello, Hermanson, \& Ye, 2011). Furthermore, communication by board subcommittees enhances their effectiveness in monitoring management for example communication by risk and remuneration committee will help the risk committee in knowing risks that may result from the actions of the remuneration committee and institute appropriate safeguards.

The study contributes to literature on RMC and corporate governance in general by providing evidence on the impact of RMC attributes on performance of finance companies in Malaysia. The study provides empirical evidence on the impact of interrelationship among board subcommittees and performance of finance companies. Unlike prior studies, this study provides evidence on the impact of risk management committee on the performance of finance companies which are usually excluded in prior studies. In terms of practical significance, the study provides regulatory authorities an insight into the risk committee attributes that influence performance and improves investors' confidence in finance companies. This will enable them to include the attributes that have significant impact on performance of finance companies in future policy formulation to enhance monitoring and safeguard the confidence of investors in the sector. The study will enable directors to improve their monitoring functions through enhanced functioning of the risk management 
subcommittee and by enhancing the interrelationship between the subcommittee and other monitoring committees thereby improving coordination and communication among the various subcommittees.

The paper is organized as follows. Section two will provide a review of the literature on RMC and subcommittees. Section three will contain the theoretical background and develop relevant hypotheses. Section four will explain the methodology while section five will present the result of the study. Section six will present result from robustness analysis while section seven will conclude the paper.

\section{Related Literature}

Risk management committee (RMC) is one of the board committees required for finance companies under the corporate governance guidelines issued by Bank Negara for licensed financial institutions. The guideline requires the committee to be composed of not less than three directors all of whom should be non-executive and to be chaired by an independent director. The guideline provided the roles and responsibilities of the RMC which includes, monitoring the risk strategies, policies and risk tolerance level as well as reviewing the sufficiency of risk management policies and framework in identifying, measuring, monitoring and controlling risk and the effectiveness of the policies and framework. Furthermore, the committee ensures that the staff responsible for risk monitoring are independent of the activity they monitor. Risk management committee performs a very important function in the monitoring of the risk and internal control in finance companies ( $\mathrm{Ng}$ et al., 2013).The risk management committee could play an important role in ensuring that the conflict of interest between the shareholders (with a diversified portfolio who may not be concerned much about risk) and the managers who are risk averse is managed through monitoring by the board (Tao \& Hutchinson, 2012). This will ensure that managers do not avoid profitable but risky projects that may enhance shareholder value.

Risk management has been the function of the audit committee but with the recent financial innovations in new financial products and the change of focus of traditional financial institutions, there is an increase need to manage risk of investing in such financial invention and the need to constantly monitor the market for such products (Merton, 1995). This inventions need to be managed by a separate and an independent risk committee composed of members with technical knowledge on the operations and products of the finance companies. The need for separate risk management committee has been emphasized because of the increase in the responsibilities imposed on the audit committee by the regulatory bodies and due to the lack of resources such as time and expertise required to provide oversight of the risks monitoring activities of the companies (Yatim, 2009). The board through its risk management committee performs the monitoring of the risk of finance companies. With shareholder value maximization in mind, the risk management committees monitors the risk taken by management (Tao \& Hutchinson, 2012) and provide advisory role concerning risk management strategies dealing with both present and future risk of the company (Walker, 2009). 
Another factor that necessitated the need for a separate RMC is the fact that the AC was negligent in monitoring in some of the companies that had corporate failure which indicated its inability to perform functions of both AC and RMCs (Bates \& Leclerc, 2009). For example in the case of Enron all the parties were found to be negligent in their duties, from the audit committee to the board as a whole and the external auditors ( $\mathrm{Li}, 2010)$. The company was found to have overstated its income for about four years and it has used some special purpose vehicles in the form of partnership to hide its liabilities.

Furthermore, the need for RMC stems from the nature of risk facing finance companies which go beyond the finance and audit risk sand include other types of business risks which include political, market and compliance risk among others (Burton, 2008). Therefore in order to ensure comprehensive monitoring of the different types of risks in finance companies, prior studies have recommended the separation of audit from risk management committee (Bugalla, Kallman, Lindo, \& Narvaez, 2012). The central bank of Malaysia mandated finance companies to have a separate RMC stating from 2003 (Ng et al., 2013).

Although risk management is a separate function in finance companies, members of the audit committee need to have an understanding of the risk management activities and safe guards put to monitor the risk activities to ensure check and balance ( $\mathrm{Ng}, 2013)$.

\section{Theoretical Background and Hypotheses Development}

Since risk is inherent in all business activities, it is important for the business to understand the risks it faces and to put adequate measures to prevent, reduce or deal with the risks (Krause, 2006). Monitoring of risks is necessary since excessive risks could make companies to sustain huge losses and also lead to problem for the whole financial system and the entire economy (Ng, 2013). Having separate board committees saddled with specific aspect of the board functions enable the directors to concentrate and specialize on a specific area and devote more time to their work through improvement in attendance at board and committee meetings (Harrison, 1987). Therefore, having separate RMC will lead to better monitoring of risk which will reduce losses and enhance performance. Prior studies have shown that it is better to delegate the functions of the board to the subcommittees than performing the functions directly by the board as a whole. This is because having separate committees performing the oversight functions of the board is more beneficial to the company by leading to specialization and improvement in performance (Klein, 1998).

The effective oversight of the RMC will ensure that managers are prevented from taking excessive risk which could bring loses and affect performance of the company (Gordon, 2010). According to Ntim (2009) the presence of board committees has no impact on performance of companies in South Africa except NC. The presences of separate RMC in Australian companies have been found to be associated with the presence of large size board, high risk and simple organizational structure and operations (Subramaniam et al., 2009). According to Tao and Hutchinson (2012), the presence of risk management committee is positively associated with good performance. Their study also found that size of RMC plays an important role in managing the risk of finance companies and enhancing their performance. 


\subsection{Committee Composition}

The effectiveness of the committee depends on the composition of the committee. A committee composed of INED will be in a better position to monitor the risk taking activities of the managers and ensures the strategies put to safeguard the company are operational (Tao \& Hutchinson, 2012). Independence of the members of risk committee enable them to with stand any pressure from management and obtain all the necessary information for monitoring risks of companies which will result in better monitoring and control of the risk of the company and ultimately lead to enhanced firm performance (Yeh, Chung, \& Liu, 2011). Minton, Tailard \& Williamson (2010) found that independence of risk committee members reduces risk taking activities of insiders leading to a decrease in losses especially during financial crisis. In the same line, Pathon (2009) reported a negative relationship between independence of RMC members and risk in finance companies. This could be attributed to the fact that the independent directors can balance the interest of different stakeholders. Yeh et al. (2011) found that finance companies with more independent directors on risk committee perform better during the financial crisis compared to those with less independent directors.

H1 There is asignificant relationship between risk management subcommittee with majority independent directors and corporate performance of finance companies.

\subsection{Independent Committee Chair}

From the perspective of agency theory, presence of independent director as committee chair ensure that the interest of the shareholders are protected by providing more effective monitoring of the risk taking activities of managers since the independent chair will ensure the committee is independent of the management. On the other hand, stewardship theory suggests that independent directors and independent chair may not be effective in monitoring due to their lack of technical knowledge of the company and its operations and that the independence of the directors on the committee will lead more and unnecessary monitoring which may hinder management initiative in taking decisions especially where urgent attention or action is needed.

H2 There is a significant relationship between independent chair of risk management subcommittee and corporate performance of a finance company.

\subsection{Expertise of Directors}

RMC with expert directors will be in a better position to monitor the risks and risk management policies and procedure due to their background and experience (Yatim, 2009). Furthermore, competence of the committee members in accounting will determine their ability to detect and manage risk to enhance the performance of companies. Directors need to have certain level of financial literacy to be able to understand the products and operations of financial institutions and risk faced by those companies (Raber, 2003). Dionne \& Triki (2005) found significant relationship between the level of director's financial knowledge and their ability to manage a firm's risk. 
H3 There is a significant relationship between risk management committees' expertise and corporate performance of finance companies.

\subsection{Prior Experience}

Directors on RMC require experience of the business of the company to be able to monitor the risk of the company (Tao \& Hutchinson, 2012). The experience they added could be acquired through serving on the board or from working in finance industry. The ability of the directors to provide effective monitoring of the risks of companies is enhanced if the directors have experience of the industry or serving in similar position (Yatim, 2009).

H4 There is a significant relationship between presence of NED with executive experience on risk management subcommittee and performance of finance companies.

\subsection{Executive Membership}

The presence of executive directors on RMC will provide the committees with valuable and high quality inside information which could be difficult to obtain by outsiders (Aguilera Desender, \& De Castro, 2011). On the other, the presence of executive especially the CEO and CFO on subcommittee could hinder the committees' effective oversight of risk and risk taking activities (Carcello, 2011). Grove, Patelli, Victoravich \& Pisun (2011) argued with the complexity in operations and increase in information asymmetry in finance companies, executive membership of subcommittees will amplify agency problem, weaken the monitoring mechanism and overall lead to poor performance by companies.CEO presence on risk committee may hinder the ability of the directors to provide good monitoring of the risk taking activities of the management (Tao \& Hutchinson, 2012).

H5 There is a significant relationship between membership of executive on risk management subcommittee and performance of finance companies.

\subsection{Interlock of Directors on Subcommittees}

Tao \& Hutchinson (2012) found that when directors are on both RMC and RC there is a reduction in the risk through enhanced communication between the committees and a significantly positive relationship with performance of companies in Australia. This is facilitated by their access to information on the level of firm's risk and the factors that may motivate risk taking in the compensation plan. On the other hand, Hoitash \& Hoitash (2009) are of the opinion that simultaneous membership on board subcommittee may hinder effectiveness in the performance of oversight functions due to conflict that may arise from the different objectives of the committees. For example the remuneration committee may be interested in giving executive a compensation package in accordance with performance of the company while the risk management committee may be interested in compensation package that may minimize the possibility of excessive risk taking (Hoitash \& Hoitash, 2009). In addition, Laux \& Laux (2007) argued that simultaneous membership of director on the board subcommittees might enhance the oversight functions of directors since directors are involved in decision in more than one committee and therefore they are more likely to take a wider view in their decisions and not only focus on the decisions of their individual 
committee. Simultaneous membership of committees will reduce information asymmetry problem, help align the interest of members and ensure better communication and coordination of the activities of the committees thereby enhancing the risk management functions and ultimately enhancing performance (Tao \& Hutchinson, 2012).

H6 There is a significant relationship between dual membership of directors on risk and other monitoring committees and performance of finance companies.

\section{Methodology}

The sample for the study comprised of 37 listed finance companies that are listed under the finance sector of the main market of Bursa Malaysia. The companies comprise of finance companies operating in different segments of the finance industry such as commercial banking, investment banking, insurance, Islamic banking, stock broking services and wealth management. The data on committee variables was obtained from annual reports of companies while the financial information was obtained from Bloomberg database. The observation period for the study covers year 2007-2011. Multiple regression analysis was used to analyze the data. The following regression model will be estimated for the risk committee attributes;

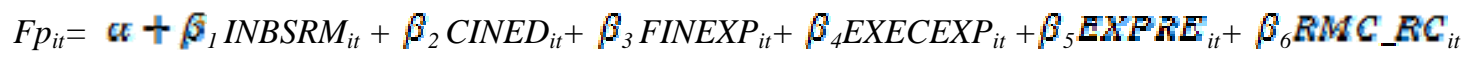

$$
\begin{aligned}
& +\beta_{7} \text { RMS }_{-} N C_{i t}+\beta_{8} \operatorname{SIZE}_{i t}+\beta_{9} L E V E R A G E_{i t}+Y D_{i t}+\varepsilon_{i t}
\end{aligned}
$$

The variables in the research model will be measured as follow:

Firm Performance $=$ Return on Assets (ROA) and Tobin's Q.

INBSRM $=$ proportion of INED to number of directors on the subcommittee

$\mathrm{CINED}=$ dummy variable of one if subcommittee chair is INED director zero otherwise

FINEXP $=$ proportion of directors with accounting qualification or finance industry experience on the subcommittee

EXECEXP $=$ proportion of directors with executive experience on the subcommittee

$\mathrm{EXPRE}=$ proportion of executive on the committee

INTERLOCK $=$ proportion of directors on both risk and remuneration subcommittees to total number of directors on the risk subcommittee

INTERNOM proportion of directors on both risk and nomination subcommittees to total number of directors on the risk subcommittee

$\mathrm{SIZE}=\log$ of total assets

LEVERAGE $=$ Ratio of total debt to equities 
Size and leverage will be used as controls variables to reduce the potential endogeneity problem from omitted variables bias. Sufian \& Habibullah (2010) reported that size is significantly positively related with performance of finance companies and this could be due to the market power of large companies and due to the efficiency of their services as a result of the quality of their employees.

\section{Empirical Result}

\subsection{Descriptive Statistics}

The result of the descriptive statistics presented in Table 1 indicates that the data is normally distributed. This could be observed by looking at the skewness and kurtosis values obtained for each variable. In addition to skewness and kurtosis for individual variables, group normality test was performed and the result obtained indicates that the data is normally distributed since the skewness and kurtosis values (0.349 and 9.46) obtained are within \pm 3.00 and \pm 10.00 range.

The result of the correlation analysis presented in Table 2 below indicates no multicollinearity problem since none of the bivariate correlation is greater than 0.9 as suggested by Kennedy (2003). In addition, linearity assumption is also fulfilled since all the values as indicated by the Q-Q plot are within \pm 3.00 threshold.

Table 1. Result of descriptive statistics

\begin{tabular}{|l|l|l|l|l|l|l|l|l|l|l|l|}
\hline & ROA & TQ & CC & CINED & FE & EE & EP & RM/R & RMC/NC & FS & LEV \\
\hline Mean & 0.024 & 0.010 & 0.265 & 0.380 & 0.146 & 0.068 & 0.024 & 0.189 & 0.254 & 0.043 & 0.042 \\
\hline Median & 0.015 & 0.010 & 0.000 & 0.000 & 0.000 & 0.000 & 0.000 & 0.000 & 0.000 & 0.038 & 0.036 \\
\hline Maximum & 0.079 & 0.013 & 1.000 & 1.000 & 0.800 & 0.750 & 0.333 & 1.000 & 1.000 & 0.088 & 0.088 \\
\hline Minimum & 0.002 & 0.009 & 0.000 & 0.000 & 0.000 & 0.000 & 0.000 & 0.000 & 0.000 & 0.025 & 0.025 \\
\hline Std.Dev. & 0.019 & 0.004 & 0.362 & 0.486 & 0.238 & 0.162 & 0.077 & 0.292 & 0.362 & 0.012 & 0.012 \\
\hline Skewness & 1.253 & 1.647 & 0.812 & 0.492 & 1.427 & 2.540 & 3.066 & 1.369 & 0.959 & 0.737 & 0.790 \\
\hline Kurtosis & 3.265 & 5.500 & 1.972 & 1.242 & 3.708 & 8.988 & 10.93 & 3.678 & 2.295 & 2.675 & 2.776 \\
\hline Obs. & 163 & 163 & 163 & 163 & 163 & 163 & 163 & 163 & 163 & 163 & 163 \\
\hline
\end{tabular}

Note. $\mathrm{ROA}=$ return on assets, $\mathrm{Q}=$ Tobin's $\mathrm{Q}$ ratio, $\mathrm{CC}=$ committee composition, $\mathrm{CINED}=$ chair independent non-executive director, $\mathrm{FE}=$ finance expertise, $\mathrm{EE}=$ executive experience, $\mathrm{EP}=$ membership of executive, $\mathrm{RM} / \mathrm{R}=$ risk/remuneration committee interlock, RMC/NC=risk management/nomination committee interlock, $\mathrm{FS}=$ firm size, LEV=leverage.

The result of heteroskedasticity test indicates that the null hypothesis of no heteroskedasticity is supported when ROA was used as the dependent variable while the hypothesis was rejected when Tobin's Q was used as the dependent variable implying that the model has heteroskedasticity problem. White's heteroskedasticity-consistent standard error was used to correct the heteroskedasticity problem, while autocorrelation problem was corrected by using the white diagonal method. 


\section{Macrothink}

Table 2. Result of correlation analysis

\begin{tabular}{|l|l|l|l|l|l|l|l|l|l|l|l|}
\hline & ROA & $\mathbf{Q}$ & CC & CINED & FE & EE & EP & RMC/RC & RMC/NC & FS & LEV \\
\hline ROA & 1.000 & -0.012 & -0.087 & -0.121 & -0.007 & -0.173 & 0.086 & -0.047 & -0.126 & 0.113 & -0.403 \\
\hline Q & -0.012 & 1.000 & -0.061 & -0.015 & -0.039 & 0.034 & 0.117 & -0.140 & -0.052 & 0.086 & -0.367 \\
\hline CC & -0.087 & -0.061 & 1.000 & 0.936 & 0.743 & 0.517 & 0.080 & 0.803 & 0.851 & 0.172 & 0.411 \\
\hline CINED & -0.121 & -0.015 & 0.936 & 1.000 & 0.787 & 0.539 & 0.233 & 0.785 & 0.898 & 0.139 & 0.282 \\
\hline FE & -0.007 & -0.039 & 0.743 & 0.787 & 1.000 & 0.311 & 0.350 & 0.706 & 0.822 & -0.051 & 0.160 \\
\hline EE & -0.173 & 0.034 & 0.517 & 0.539 & 0.311 & 1.000 & -0.050 & 0.379 & 0.402 & 0.075 & 0.318 \\
\hline EP & 0.086 & 0.117 & 0.080 & 0.233 & 0.350 & -0.050 & 1.000 & 0.293 & 0.225 & 0.004 & -0.169 \\
\hline RMC/RC & -0.047 & -0.140 & 0.803 & 0.785 & 0.706 & 0.379 & 0.293 & 1.000 & 0.842 & 0.168 & 0.313 \\
\hline RMC/NC & -0.126 & -0.052 & 0.851 & 0.898 & 0.822 & 0.402 & 0.225 & 0.842 & 1.000 & 0.070 & 0.253 \\
\hline FS & 0.113 & 0.086 & 0.172 & 0.139 & -0.051 & 0.075 & 0.004 & 0.168 & 0.070 & 1.000 & 0.058 \\
\hline LEV & -0.403 & -0.367 & 0.411 & 0.282 & 0.160 & 0.318 & -0.169 & 0.313 & 0.253 & 0.058 & 1.000 \\
\hline
\end{tabular}

Note. $\mathrm{ROA}=$ return on assets, $\mathrm{Q}=$ Tobin's $\mathrm{Q}$ ratio, $\mathrm{CC}=$ committee composition, $\mathrm{CINED}=$ chair independent non-executive director, $\mathrm{FE}=$ finance experience, $\mathrm{EE}$ =executive experience, $\mathrm{EP}=$ membership of executive, $\mathrm{RMC} / \mathrm{RC}=$ risk/remuneration committee interlock, RMC/NC=risk management/nomination committee interlock, FS=firm size, LEV=leverage.

\subsection{Multivariate Regression Analysis}

The result of the regression analysis presented is based on FEM. The adjusted $\mathrm{R}^{2} 0.6051$ obtained as presented in Table 3below implies that the variables explain approximately61\% of the variation in ROA. The F-statistics (6.6921) is and the corresponding $p$-value $(p<0.01)$ is highly significant or lower than the alpha value of 0.05 . This indicates that the slope of the estimated panel least squares regression model line is not equal to zero confirming that the research data fit the proposed nine predictor model of the study.

Table 3. Summary of multivariate regression analysis based on ROA

\begin{tabular}{|l|l|l|l|}
\hline & Pooled (OLS) & REM & FEM \\
\hline Constant & $0.021(2.396)^{* *}$ & $0.028(2.978)^{* * *}$ & $0.034(4.086)^{* * *}$ \\
\hline Composition & $0.046(2.997)^{* * *}$ & $0.002(0.103)$ & $-0.040(-2.123)^{* *}$ \\
\hline Chair independent & $-0.020(-1.483)$ & $0.011(0.473)$ & $0.035(2.138)^{* *}$ \\
\hline Finance expertise & $0.021(1.627)$ & $-0.001(-0.111)$ & $-0.020(-1.400)$ \\
\hline Executive experience & $0.012(0.807)$ & $0.020(1.328)$ & $0.038(2.146)^{* *}$ \\
\hline Executive presence & $0.0003(0.010)$ & $-0.019(-0.453)$ & $-0.077(-1.986)^{* *}$ \\
\hline RMC/RC & $0.017(1.723)^{*}$ & $0.014(1.205)$ & $0.004(0.220)$ \\
\hline RMC/NC & $-0.035(-2.449)^{* *}$ & $-0.025(-1.575)$ & $-0.0147(-1.350)$ \\
\hline Firm size & $0.291(1.701)^{*}$ & $0.083(0.478)$ & $-0.042(-0.275)$ \\
\hline Leverage & $-0.267(-5.707)^{* * *}$ & $-0.204(-3.598)^{* * *}$ & $-0.114(-1.867)^{*}$ \\
\hline 2008 & $0.0190(2.580)^{* *}$ & $0.016(3.082)^{* * *}$ & $0.014(2.836)^{* * *}$ \\
\hline
\end{tabular}




\begin{tabular}{|l|l|l|l|}
\hline 2009 & $0.0024(0.3298)$ & $-0.0002(-0.037)$ & $-0.002(-0.338)$ \\
\hline 2010 & $0.0038(0.748)$ & $0.002(0.624)$ & $0.001(0.320)$ \\
\hline 2011 & $0.0031(0.5484)$ & $0.002(0.487)$ & $0.0007(0.165)$ \\
\hline R squared & 0.3035 & 0.1638 & 0.7114 \\
\hline Adjusted R squared & 0.2499 & 0.0995 & 0.6051 \\
\hline F-statistics & $5.6661^{* * *}$ & $2.547885^{* * *}$ & $6.692161^{* * *}$ \\
\hline Durbin Watson stat & 1.1062 & 1.648328 & 2.208746 \\
\hline Hausman's test & NA & NA & $29.6333(0.0018)$ \\
\hline
\end{tabular}

Note. $*, * *, * * *$ indicates $\mathrm{p}$ value is significant at $10 \%, 5 \%$ and $1 \%$ level. Coefficient first and t-statistics in parenthesis. OLS=ordinary least square, REM=random effect method, FEM=fixed effect method, 2007 is used as the based year.ROA=return on assets measured as EBIT divided by total assets, CC=committee composition defined as the proportion of Independent directors to total number of directors on RMC, CINED=chair independent non-executive director defined as a dummy variable that takes one if committee chair is independent zero otherwise, $\mathrm{FE}$ =finance expertise measured as the number of directors with accounting expertise or finance industry experience divided by the total number of directors on RMC, EE=executive experience measured as the number of directors with executive experience divided by the total number of directors on $\mathrm{RMC}, \mathrm{EP}=$ membership of executive number of executive directors on AC divided by total number of directors on RMC, $\mathrm{RMC} / \mathrm{RC}=$ risk management/remuneration committee interlock, $\mathrm{RMC} / \mathrm{NC}=$ risk/nomination committee interlock, interlock is defined as the number of directors on RMC and other monitoring committees divided by total number of directors on RMC, FS=firm size (log of total assets), LEV=leverage measured as total debt divided by equity.

Based on the result in the table above, 5 of the predictor variables were significant. In addition, the result presented in Table 3 indicates that the largest coefficient obtained was -0.114 for leverage with a corresponding t-statistics of -1.867 . This means that leverage made the strongest single contribution in explaining the dependent variable ROA when the contribution of other variables in the model was controlled for. It suggests that one standard deviation increase in leverage is followed by -0.114 standard deviation change in ROA. Membership of executive made the second highest contribution with a coefficient value of -0.077 while independent committee chair made the lowest contribution (0.035).

Hypothesis 1 predicted a relationship between independent RMC and ROA. The result obtained indicated that independent RMC is significantly negatively related with ROA ( $\mathrm{p}<$ 0.05). This is contrary to the theoretical expectation based on agency theory and contrary to evidence reported by Tao \& Hutchinson (2012), Yeh et al. (2011) and Minton et al. (2010). The negative association could be explained by inadequate monitoring by INED due to their busy schedule or due to inadequate technical knowledge and experience needed to perform the monitoring role effectively (Klein, 1998; Tao \& Hutchinson, 2012). On the other hand, the result supports stewardship theory which suggests that executive directors are good stewards and due to their superior knowledge of the business which will enable them to provide better monitoring of the business of the company.

The second hypothesis predicted (H2) a relationship between independent RMC chair and ROA. The result indicated significant positive relationship $(\mathrm{p}<0.05)$ between independent 
committee chair and ROA. This supports the requirements of the central bank and agency theory expectations since independent chair will be able to ensure that conflict of interest between shareholders and managers is effectively managed.

The study hypothesized a relationship between finance expertise of directors on RMC and ROA (H3). The result obtained shows that finance expertise of directors on RMC has a negative (but insignificant) relationship with ROA. This is contrary to findings by Raber (2003), Dionne \& Triki (2005) who reported that the ability of the directors to monitor risk effectively depends on the level of financial literacy of directors.

Hypothesis 4 predicted a relationship between executive experience and firm performance. The result obtained indicates a positive and significant relationship between ROA and executive experience of RMC members. The result supports evidence documented by Tao and Hutchinson (2012) who argued that RMC members need to be experienced to be able to monitor risk of a finance company.

Hypothesis 5 hypothesized a relationship between membership of executive on RMC and ROA. The result indicates a significant negative relationship between executive membership of RMC and ROA. This is contrary to arguments by (Klein, 1998, Tao \& Hutchinson, 2012) who suggests that executive membership of RMC will provide the committee with inside information that may help their risk monitoring activities and enhance company performance. On the other hand, the result is consistent with agency theory and evidence from Carcello et al. (2011) who reported that executive membership of subcommittee could affect monitoring of risk.

Hypothesis 6 predicted a relationship between interlock of directors on risk and RC and firm performance. The result indicates an insignificant positive relationship between interlock of directors on RMC and RC and ROA. This is contrary to findings by Tao and Hutchinson (2012) and also agency theory which assumes that interlock of directors will enhance performance by reducing information asymmetry and enhancing coordination among the subcommittees of the board. On the other hand, the positive sign is contrary to argument by Hoitash \& Hoitash (2009) that interlock of directors on subcommittee negatively affects firm performance due to conflicting objectives among the committees.

A relationship was predicted between interlock of directors on RMC and NC and firm performance. The result obtained shows a negative but insignificant relationship between interlock on RMC and NC and ROA. This is contrary to agency theory which posits a reduction in information asymmetry when directors are on more than one committee. In contrast, the result supports findings by Hoitash \& Hoitash (2009) who argued that interlock could lead to poor performance due to conflict in objectives of the committees. The result reported indicates a significant negative relationship between leverage and ROA ( $p<0.1)$ while firm size has an insignificant negative relationship with ROA.

\subsection{Result Based on Market Measure of Performance}

To determine which of the panel specification method is most appropriate, the Hausman's test was performed. The result of the test indicated that REM is the most appropriate method 
to use. The adjusted $\mathrm{R}^{2}$ of 0.1590 implies that the variables collectively explain $15.9 \%$ of the variation in firm performance. The F-statistics (3.357) was large and the corresponding p-value was highly significant or lower than the alpha value of 0.05 . This indicates that the slope of the estimated least squares regression model line is not equal to zero confirming that the research data fit the proposed nine predictor model of the study.

As shown by the result presented in Table 4, leverage made the largest contribution in explaining the dependent variable (Tobin's Q) the coefficient obtained was -0.038 with a corresponding t-statistics of -5.769 . This means that leverage made the strongest contribution in explaining the dependent variable firm performance when the contribution of other variables in the model was controlled for. It suggests that one standard deviation increase in leverage is followed by -0.038 standard deviation change in performance. The lowest contribution was made by committee composition with coefficient 0.0074 .

The study predicted a relationship between composition of RMC and market performance. The result indicates a significant positive relationship between firm performance and composition of RMC ( $\mathrm{p}<0.05)$. The result is in line with theoretical expectations and in line with prior studies such Carson (2002), Xie, Davidson \& Dadalt (2003). This is explained by enhanced monitoring of the management by the board due the absence of any association between the independent directors and executive.

The study hypothesized a relationship between independent committee chair and firm performance. The result obtained indicates a negative but insignificant relationship between chair independence and Tobin's Q. This is contrary to theoretical expectations of agency theory and prior studies such as (Carson, 2002) who argued that to ensure the effectiveness of a committee, the board subcommittees should have more independent directors and independent chair.

Table 4. Summary of multivariate regression based on Tobin’s Q

\begin{tabular}{|l|l|l|l|}
\hline & Pooled (OLS) & REM & FEM \\
\hline Constant & $0.007(5.381)^{* * *}$ & $0.007(5.512)^{* * *}$ & $0.007(4.594)^{* * *}$ \\
\hline Composition & $0.006(1.894)^{*}$ & $0.007(2.020)^{* *}$ & $0.011(2.255)^{* *}$ \\
\hline Chair independent & $-0.003(-1.132)$ & $-0.003(-1.029)$ & $-0.004(-1.456)$ \\
\hline Finance expertise & $-0.002(-0.910)$ & $-0.003(-1.174)$ & $-0.005(-1.482)$ \\
\hline Executive experience & $0.005(2.443)^{* *}$ & $0.005(1.930)^{* *}$ & $0.005(1.232)$ \\
\hline Executive presence & $0.012(2.211)^{* *}$ & $0.007(1.046)$ & $0.009(0.690)$ \\
\hline RMC/RC & $-0.007(-2.887)^{* * *}$ & $-0.003(-1.249)$ & $0.002(0.828)$ \\
\hline RMC/NC & $0.003(1.163)$ & $0.0006(0.234)$ & $-0.001(-0.551)$ \\
\hline Firm size & $0.032(1.366)$ & $0.029(1.193)$ & $0.024(0.876)$ \\
\hline Leverage & $-0.031(-5.613)^{* * *}$ & $-0.038(-5.769)^{* * *}$ & $-0.041(-4.974)^{* * *}$ \\
\hline 2008 & $-0.0007(-0.715)$ & $-0.0004(-0.522)$ & $-0.0002(-0.247)$ \\
\hline 2009 & $0.0003(0.323)$ & $0.0006(0.8814)$ & $0.001(1.274)$ \\
\hline 2010 & $0.0005(0.619)$ & $0.0008(1.140)$ & $0.00117(1.328)$ \\
\hline
\end{tabular}




\begin{tabular}{|l|l|l|l|}
\hline 2011 & $0.001(1.787)^{*}$ & $0.001(2.272)^{* *}$ & $0.0019(2.357)^{* *}$ \\
\hline R squared & 0.2565 & 0.2265 & 0.6384 \\
\hline Adjusted R squared & 0.1917 & 0.1590 & 0.4906 \\
\hline F-statistics & $3.955^{* * *}$ & $3.357^{* * *}$ & $4.320^{* * *}$ \\
\hline Durbin Watson stat & 1.020 & 1.608 & 2.044 \\
\hline Hausman's test & NA & $5.7925(0.8868)$ & NA \\
\hline
\end{tabular}

Note. $*, * *, * * *$ indicates $\mathrm{p}$ value is significant at $10 \%, 5 \%$ and $1 \%$ level. Coefficient first and t-statistics in parenthesis. OLS=ordinary least square, REM=random effect method, FEM=fixed effect method, year 2007 is used as the based year.CC=committee compositional number of directors on AC, CINED=chair independent non-executive director, $\mathrm{FE}=$ finance expertise, $\mathrm{EE}=$ executive experience, $\mathrm{EP}=$ membership of executive, $\mathrm{A} / \mathrm{RC}=$ audit/remuneration committee interlock, $\mathrm{A} / \mathrm{RMC}=$ audit/risk committee interlock, $\mathrm{A} / \mathrm{NC}=$ audit/nomination committee interlock, FS=firm size, LEV=leverage.

A relationship between finance expertise of RMC members and firm performance was predicted. The result depicts that expertise of members on RMC does not have a significant relationship with firm performance. The negative sign is contrary to prior studies such as Akhigbeand Martin (2006) who found that expertise of committee members determine their ability to adequately monitor management and prevent taking excessive risk thereby enhancing performance. Lack of significance of the directors' expertise could imply that expertise of directors in accounting may not necessary serve as a good monitoring mechanism but expertise in finance and possession of other finance related qualification and experience may enable the directors to provide adequate monitoring of the operations and sophisticated products of finance companies.

Executive experience was predicted to have a relationship with firm performance. The result obtained indicates that executive experience is positively related with firm performance and the relationship is significant $(\mathrm{p}<0.05)$. This is in line with prior studies such as Akhigbeand Martin (2006) who found that experience of members of RMC will determine their ability to provide adequate monitoring and advice to the management.

The study hypothesized a relationship between membership of executive on RMC and firm performance. The result presented above indicates a positive but statistically insignificant relationship between membership of executive on RMC and firm performance. The positive sign supports prior studies which reported that executive membership of subcommittee will enhance performance by providing the subcommittee with inside information which would not be available to outsiders (Aguilera et al., 2011).On the other hand, executive could hinder effective monitoring when they are on a subcommittee Carcello et al. (2011).

The study hypothesized a relationship between interlock of directors on RMC and RC. The result obtained indicates no significant relationship between interlock on RMC and RC and firm performance. The negative direction indicated by the result is contrary to findings from Tao \& Hutchinson (2012) who reported significant positive relationship between interlock on RMC and RC and firm performance but similar to Hoitash \& Hoitash (2009) who reported negative relationship due to conflict between committee objectives. 
A relationship between the interlock on RMC and NC and firm performance was predicted, however, the result obtained found an insignificant positive relationship between interlock on RMC and NC and firm performance. The positive sign support the proposition based on agency theory that interlock helps to reduce information asymmetry among directors on different committees and enhance coordination. In addition, the result revealed that leverage was significantly ( $\mathrm{p}<0.01$ ) negatively related with Tobin's $\mathrm{Q}$ while firm size was positive but insignificantly related with market performance.

\subsection{Comparison of the Result for the Period before and after the Revision}

The composition of RMC committee varies with an average of $18 \%$ and $28 \%$ independent directors for the period before and after respectively while the maximum and minimum proportion of independent directors on the committee is $100 \%$ and zero. The percentage of RMC with independent chair increased from $29.7 \%$ before the revision to $36.9 \%$ after the revision. This indicates that the revision of the code had a positive impact on the independence of the RMC as evidenced by the increase in independent directors and committees chaired by independent directors.

The maximum number of directors with accounting expertise or finance industry experience has decreased from $100 \%$ in the period before the revised code to $80 \%$ after the revision while the minimum is zero in both periods. However, the average for the period before is $13.3 \%$ while for the period after is $13.8 \%$. This indicates a slightly increase in the number of expert directors on RMC. In addition, the maximum number of directors with executive experience on RMC has decreased from $100 \%$ to $80 \%$ with an average of $25.6 \%$ and $9.8 \%$ for the period before and after the revised code. This could be as a result of the increase in the number of independent directors appointed to the committee who may not have accounting background or finance industry experience.

The percentage of executive on RMC has reduced from a maximum of $66.7 \%$ to $33.3 \%$ with an average of $2.7 \%$ and $2.3 \%$ for the period before and after respectively. The minimum in both periods is zero. The reduction in the proportion of executive on RMC indicates that the principles of the code have impacted on the composition of the RMC. The maximum value for interlock of directors on RMC and RC is $100 \%$ with a minimum of zero and an average of $18.9 \%$ and $19.3 \%$ for the period before and after the revision. The interlock of directors on RMC and NC has changed from a maximum of $50 \%$ to $100 \%$ and from an average of $4.7 \%$ to $24.4 \%$ with a minimum of zero in both period before and after respectively. The result indicates that interlock of directors on subcommittees has increased in the period after compared to the period before.

\subsection{Multivariate Regression for the Period before and after Revision of MCCG}

The result obtained for the RMC is based on FEM as indicated by the result of the Hausman's. The result indicates that the variables explain approximately $63 \%$ and $81 \%$ of the variation in ROA for the period before and after the revision respectively with f-statistics value of 5.0178 and 10.8072 and a corresponding p-value lower than the alpha of 0.05 in both periods. 
In terms of the independent variables, none of the variables have significant relationship with the ROA for both periods.

Table 6. Multivariate regression for RMC model based on ROA for both periods

\begin{tabular}{|l|l|l|}
\hline & Period before & Period after \\
\hline C & $0.044788(1.877263) *$ & $0.023512(2.598609) * * *$ \\
\hline CC & $0.005474(0.111723)$ & $-0.021339(-0.977036)$ \\
\hline CINED & $-0.004542(-0.172726)$ & $-0.016338(-0.733030)$ \\
\hline FE & $-0.001739(-0.057235)$ & $0.016146(0.886350)$ \\
\hline EE & $-0.013687(-0.352279)$ & $0.023127(1.050352)$ \\
\hline EP & $-0.054126(-0.860054)$ & $-0.042904(-0.853949)$ \\
\hline RMC_RC & $0.001864(0.073007)$ & $0.025766(1.349771)$ \\
\hline RMC_NC & $0.035927(0.423765)$ & $0.005652(0.313826)$ \\
\hline TA2 & $-0.331806(-0.481600)$ & $0.146767(0.867781)$ \\
\hline LEV2 & $0.013715(0.547674)$ & $-0.056595(-1.243749)$ \\
\hline Year dummy & $-0.004158(-0.759662)$ & $0.000261(0.093817)$ \\
\hline Year dummy & $-0.002374(-0.425536)$ & $-0.000109(-0.036093)$ \\
\hline$R^{2}$ & 0.789183 & 0.889656 \\
\hline Adj R & 0.631907 & 0.807336 \\
\hline F-statistic & $5.017819 * * *$ & $10.80726 * * *$ \\
\hline Durbin-Watson stat & 2.272033 & 3.261219 \\
\hline
\end{tabular}

Note. $* * *, * *, *$ indicates significant at $1 \%, 5 \%$ and $10 \%$ respectively.

The result obtained for the RMC model based on Tobin's Q indicates that the variables explain approximately $42 \%$ and $14 \%$ of the variation in firm performance for the period before and after respectively. The F-statistics obtained is large and the corresponding p-value is significant or lower than the alpha value of 0.05 . This indicates that the slope of the estimated regression model is not equal to zero confirming that the research data fit the proposed least squares model of the study.

In case of the individual variable, RMC composition and executive experience are significantly positively related with Tobin's $Q$ at $5 \%$ level each while leverage is significantly negatively related with Tobin's Q at 1\% level of significance for the period after the revision. However, the remaining variables and all the variables in the period before the revision were not significant. 
Table 7. Multivariate regression for RMC model based on Tobin's Q for both periods

\begin{tabular}{|l|l|l|}
\hline & Period before & Period after \\
\hline C & $0.006643(3.153836)^{* *}$ & $0.008136(4.569790)^{* * *}$ \\
\hline INED & $-0.000820(-0.189533)$ & $0.009681(2.169137)^{* *}$ \\
\hline CINED & $-0.001314(-0.565872)$ & $-0.004919(-1.384013)$ \\
\hline FE & $0.001020(0.380361)$ & $-0.002663(-0.708916)$ \\
\hline EE & $-0.000535(-0.155850)$ & $0.007663(2.236995)^{* *}$ \\
\hline EP & $0.001791(0.322288)$ & $0.012526(1.512107)$ \\
\hline RM_REM & $0.001376(0.610490)$ & $-0.005156(-1.533109)$ \\
\hline R_N & $-0.002527(-0.337555)$ & $0.001782(0.518534)$ \\
\hline TA & $0.073851(1.214060)$ & $0.025839(0.733867)$ \\
\hline LEV & $0.001380(0.624314)$ & $-0.032014(-3.680449)^{* * * *}$ \\
\hline Year dummy & $-0.000904(-1.870187)^{*}$ & $0.001079(1.352396)$ \\
\hline Year dummy & $-0.000561(-1.139139)$ & $-0.000861(-1.036947)$ \\
\hline $\mathrm{R}^{2}$ & 0.665678 & 0.235244 \\
\hline Adjusted $\mathrm{R}^{2}$ & 0.416262 & 0.139650 \\
\hline F-statistic & $2.668954^{* * *}$ & $2.460856 * * *$ \\
\hline \multicolumn{1}{|c|}{ Durbin-Watson stat } & 2.132874 & 2.090910 \\
\hline
\end{tabular}

Note. ${ }^{* * *}, * *, *$ indicates significant at $1 \%, 5 \%$ and $10 \%$ respectively.

\section{Additional Analysis}

Our regression analysis so far has not taken into consideration the potential endogeneity problem implying that our result may be spurious. In this section we examine the robustness of our result to endogeneity problem. In order to account for potential endogeneity problem in our regression, and following prior studies we employ the generalized method of moments method (Blundell \& Bond, 1998; Sufian \& Habibullah, 2010).

In the case of coefficient of the variables for RMC some cases of sensitivities could be observed. Firstly, the coefficient of committee composition has changed from significant to statistically insignificant under ROA in column 4 but remained in the same direction. In case of committee chair, the coefficient has become negative and insignificant under ROA. Secondly, coefficient of finance expertise has changed from negative to positive under ROA but remained insignificant while executive experience has changed from positive to negative under Tobin’s Q but remained significant.

Furthermore, coefficient of executive membership has changed from significant to insignificant under ROA while it has changed from positive to negative under Tobin's $Q$. The coefficient for the RMC/RC interlock has become significant under ROA but remained in the same direction while it changed to significant under Tobin's Q. In case of interlock of directors on RMC/NC the coefficient has changed from positive to negative under Tobin's Q but remained insignificant. Finally, firm size has changed from positive to negative while leverage has changed from significant to insignificant both under Tobin’s Q. 
In order to ensure that the instruments we used are strong and therefore the estimates are consistent we used the sargan test a test of over-identification restriction to test if the instruments are valid. The result obtained from the sargan test confirms that the instruments are valid. The result from the GMM estimation indicates that our result is robust to potential endogeneity problem.

Table 8. Summary of estimation based on generalized method of moments

\begin{tabular}{|c|c|c|c|c|}
\hline & \multicolumn{2}{|c|}{ Least squares models } & \multicolumn{2}{|c|}{ Generalized method of moments } \\
\hline & $\mathrm{ROA}$ & Tobin’s Q & ROA & Tobin's Q \\
\hline Constant & $0.034(4.086)^{* * *}$ & $0.007(5.512)^{* * *}$ & $0.1088(0.9069)$ & $-0.0131(0.6656)$ \\
\hline CC & $-0.040(-2.123)^{* *}$ & $0.007(2.020)^{* *}$ & $-0.0377(-0.850)$ & $0.0949(-0.4337)$ \\
\hline CINED & $0.035(2.138)^{* *}$ & $-0.003(-1.029)$ & $-0.0170(-0.439)$ & $-0.0113(1.171)$ \\
\hline FE & $-0.020(-1.400)$ & $-0.003(-1.174)$ & $0.0166(0.3515)$ & $-0.0710(-0.8699)$ \\
\hline $\mathrm{EE}$ & $0.038(2.146)^{* *}$ & $0.005(1.930)^{* *}$ & $0.1008(1.903)^{*}$ & $-0.3066(-2.671)^{* * *}$ \\
\hline $\mathrm{EP}$ & $-0.077(-1.986)^{* *}$ & $0.007(1.046)$ & $-0.1263(-1.177)$ & $-0.0510(-1.0511)$ \\
\hline $\mathrm{RMC} / \mathrm{RC}$ & $0.004(0.220)$ & $-0.003(-1.249)$ & $0.0925(2.994)^{* * *}$ & $-0.0272(-1.718)^{*}$ \\
\hline $\mathrm{RMC} / \mathrm{NC}$ & $-0.0147(-1.350)$ & $0.0006(0.234)$ & $-0.0482(-1.402)$ & $-0.0449(-0.8487)$ \\
\hline Firm size & $-0.042(-0.275)$ & $0.029(1.193)$ & $-0.0915(-0.475)$ & $-0.0033(-0.7299)$ \\
\hline Leverage & $-0.114(-1.867)^{*}$ & $-0.038(-5.769) * * *$ & $-0.0658(-1.646)$ & $-0.0004(-0.7023)$ \\
\hline 2008 & $0.014(2.836)^{* * *}$ & $-0.0004(-0.522)$ & & \\
\hline 2009 & $-0.002(-0.338)$ & $0.0006(0.8814)$ & $-0.0005(-0.149)$ & $-0.0004(-0.7470)$ \\
\hline 2010 & $0.001(0.320)$ & $0.0008(1.140)$ & $-0.0011(-0.249)$ & $-0.0031(-1.845)^{*}$ \\
\hline 2011 & $0.0007(0.165)$ & $0.001(2.272)^{* *}$ & $-0.0061(-1.321)$ & $-0.0028(-1.634)$ \\
\hline R squared & 0.7114 & 0.2265 & - & - \\
\hline Adjusted $\mathrm{R}^{2}$ & 0.6051 & 0.1590 & - & - \\
\hline F-statistics & $6.692161^{* * *}$ & $3.357 * * *$ & - & - \\
\hline DW stat & 2.208746 & 1.608 & - & - \\
\hline J-statistics & - & - & $10.9412(0.0525)$ & $2.620(0.8546)$ \\
\hline Wald test & - & - & $69.60340 * * *$ & $112.0439 * * *$ \\
\hline
\end{tabular}

Note. $*, * *, * * *$ indicates $\mathrm{p}$ value is significant at $10 \%, 5 \%$ and $1 \%$ level. Coefficient first and t-statistics in parenthesis. OLS=ordinary least square, REM=random effect method, FEM=fixed effect method, year 2007 is used as the bases year. $\mathrm{CC}=$ committee composition, $\mathrm{CINED=chair}$ independent non-executive director, $\mathrm{FE}=$ finance expertise, $\mathrm{EE}=$ executive experience, $\mathrm{EP}=$ =membership of executive on RMC, $\mathrm{RMC} / \mathrm{RC}=$ risk/remuneration committee interlock, RMC/NC=risk/nomination committee interlock, FS=firm size, LEV=leverage.

\section{Conclusion}

The paper examined the impact of RMC attributes on the performance of finance companies in Malaysia based on data obtained from the annual reports of 37 seven finance companies listed in the finance segment of the main market of Bursa Malaysia. The result obtained indicates that 
composition of the committee negatively affects accounting returns but has a positive impact on market returns. This implies that requirement for composition of the RMC comprised of majority independent directors by the central bank may not be appropriate for all finance companies and should therefore be determined by the circumstance of companies. While large companies with dispersed shareholding and greater agency problem may benefit from independent committee, small companies might benefit more from less independent committee. The result also indicates that independent committee chair positively enhance accounting returns. This could be due the independence of the committee from management and its ability to withstand pressure from the executive. The result also implies that the market does not see independent chair as good monitoring mechanism.

Executive experience is positively related with both accounting and market measure of performance. This means that companies seeking to enhance their performance should include more directors with prior executive experience on risk management committee. Finally, the presence of executive on RMC shows a significant negative relationship with ROA implying that membership of executive on the committee will reduce the accounting return of companies and implies that the recommendations of Bank Negara for RMC to be composed of non-executive directors is supported.

The significant impact of independent committee chair indicates that the requirement of BNM for independent committee chair is appropriate for finance companies. Furthermore, the regulatory authorities should consider recommending companies to include directors with prior experience on RMC since the result has shown that executive experience of directors enhances both accounting and market performance of companies. Therefore, the appointment of directors with executive experience may enhance the confidence of investors in the company and enhance investment in into the company.

The study is limited only to listed finance companies in Malaysia; future studies could examine the impact of RMC attributes on the performance of unlisted companies, companies in other sectors and economies. Future studies could examine other committee attributes such as size, individual characteristics of the directors on the committee and the internal processes of the committee.

\section{References}

Aguilera, R. V., Desender, K. A., \& De Castro, L. R. K. (2011). A configurational approach to comparative corporate governance. [Online] Available: http://ssrn.com/abstract=1797142

Akhigbe, A., \& Martin, A. D. (2006). Valuation impact of Sarbanes-Oxley: Evidence from disclosure and governance within the financial services industry. Journal of Banking and Finance, 30(3), 989-1006. http://dx.doi.org/10.1016/j.jbankfin.2005.06.002

Atik, J. (2009). Basel II and extreme risk analysis. [Online] Available: http://www.asil.org/files/atik.pdf 
Barney, J. (2009). Corporate scandals, executive compensation, and international corporate governance convergence: A U.S.-Australia case study. [Online] Available: http://works.bepress.com/jacob_barney/1

Bates, E. W. II., \& Leclerc, R. J. (2009). Boards of directors and risk committees. The Corporate Governance Advisor, 17, 15-17.

Beasley, M. S., Clune, R., \& Hermanson, D. R. (2005). Enterprise Risk Management: An Empirical Analysis of Factors Associated with the Extent of Implementation. Journal of Accounting and Public Policy, 24(6), 521-531. http://dx.doi.org/10.1016/j.jaccpubpol.2005.10.001

Becht, M., Bolton, P., \& Roell, A. (2011). Why bank corporate governance is different. Oxford Review of Economic policy, 27(3), 437-463. http://dx.doi.org/10.1093/oxrep/grr024

Blundell, R., \& Bond, S. (1998). Initial conditions and moment restrictions in dynamic panel data models. Journal of Econometrics, 87(1), 115-143. http://dx.doi.org/10.1016/S0304-4076(98)00009-8

Bugalla, J., Kallman, J., Lindo, S., \& Narvaez, K. (2012). The new model of governance and riskmanagement for financial institutions. Journal of Risk Management in Financial Institutions, 5, 181-193.

Burton, E. J. (2008). The audit committee: How should it handle ERM? Journal of Corporate Accounting and Finance, 19(4), 3-5. http://dx.doi.org/10.1002/jcaf.20395

Carcello, J. V., Hermanson, D. R., \& Ye, Z. S. (2011). Corporate governance research in accounting and auditing: insights, practice implications, and future research directions. Auditing: A Journal of Practice and Theory, 30(3), 1-31. http://dx.doi.org/10.2308/ajpt-10112

Carson, E. (2002). Factors associated with the development of board sub-committees. Corporate Governance:An International review, 10(1), 4-18. http://dx.doi.org/10.1111/1467-8683.00263

Dionne, G., \& Triki, T. (2005). Risk management and corporate governance: The importance of independence and financial knowledge for the board and audit committee. Working paper 05-15. [Online] Available: http://www.his.se/PageFiles/17648/riskmanagementandgovernancepaper2005.pdf. http://dx.doi.org/10.2139/ssrn.686470

Erkens, D., Hung, M., \& Matos, P. P. (2012). Corporate governance in the recent financial crisis: Evidence from financial institutions worldwide. Journal of Corporate Finance, 18, [Online] Available: http://ssrn.com/abstract=139685. http://dx.doi.org/10.1016/j.jcorpfin.2012.01.005

Ghazali, N. A. M. (2010). Ownership structure, corporate governance and corporate performance in Malaysia. International Journal of Commerce and Management, 20(2), 109-119. http://dx.doi.org/10.1108/10569211011057245 
Gordon, J. N. (2010). Executive compensation and corporate governance in financial firms: the case for convertible equity based-pay. [Online] Available: http://ssrn.com/abstract=1633906. http://dx.doi.org/10.2139/ssrn.1633906

Grove, H., Patelli, L., Victoravich, L. M., \& XU, P. (2011). Corporate governance and performance in the wake of financial crisis: Evidence from US commercial banks. Corporate governance: An international Review, 19(5), 418-436. http://dx.doi.org/10.1111/j.1467-8683.2011.00882.x

Harrison, J. R. (1987). The strategic use of corporate board committees. California Management Review, 30(1), 109-125. http://dx.doi.org/10.2307/41165269

Hoitash, U., \& Hoitash, R. (2009). Conflicting objectives within the board: evidence from Overlapping audit and compensation committee members. Group Decision and Negotiation, 18(1), 57-73. http://dx.doi.org/10.1007/s10726-008-9125-y

Kashyap, A., Rajan, R., \& Stein, J. (2008). Rethinking capital regulation. [Online] Available: http://scholar.harvard.edu/sites/scholar.iq.harvard.edu/files/stein/files/kashyaprajanstein.03.1

2.09.pdf

Khoon, G. S., \& Mah-Hui, M. L. (2010). The impact of global financial crisis: The case of Malaysia. Penang: Third World Network. [Online] Available: http://twnside.org.sg/title2/ge/ge26.pdf

Kim, P. K., \& Rasiah, D. (2010). Relationship between corporate governance and bank performance in Malaysia during the pre and post Asian financial crisis. European Journal of Economics, Finance and Administrative Sciences, 21, 39-63.

Klein, A. (1998). Firm performance and board committee structure. Journal of Law and Economics, 41(1), 275-304. http://dx.doi.org/10.1086/467391

Krause, A. (2006). Risk, capital requirements, and the asset structure of companies. Managerial Finance, 32, 774-85. http://dx.doi.org/10.1108/03074350610681961

Laux, C., \& Laux, V. (2009). Board committees, CEO compensation, and earnings management. The Accounting Review, 84(3), 869-891. http://dx.doi.org/10.2308/accr.2009.84.3.869

Liebenberg, A., \& Hoyt, R. (2003). The Determinants of Enterprise Risk Management: Evidence from the Appointment of Chief Risk Officers. Risk Management and Insurance Review, 6(1), 37-52. http://dx.doi.org/10.1111/1098-1616.00019

Merton, R. C. (1995). A functional perspective of financial intermediation. Financial Management, 24(2), 23-41. http://dx.doi.org/10.2307/3665532

Minton, B. A., Taillard, J. P. A., \& Williamson, R. (2011). Do independence and financial expertise of board matter for risk taking and performance. Fisher college Working Paper, No 2010-03-014. [Online] Available:http://ssrn.com/abstract=1661855. http://dx.doi.org/10.2139/ssrn.1787126 
Mohamad, W. I. A., \& Sulong, Z. (2010). Corporate governance mechanisms and extent of disclosure: Evidence from listed companies in Malaysia. International Business Research, 3(4), 216-228. http://dx.doi.org/10.5539/ibr.v3n4p216

Moosa, I. (2008). Anatomy of the subprime financial crisis. Monash Business Review, 4(1), $1-7$.

Ng, T-H., Chong, L-L., \& Ismail, H. (2013). Is risk management committee only a procedural compliance? An insight into managing risk taking among insurance companies in Malaysia. The Journal of Risk Finance, 14(1), 71-86. http://dx.doi.org/10.1108/15265941311288112

Ntim, C. G. (2009). Internal corporate governance structures and firm financial performance: evidence from South African listed companies. Unpublished $\mathrm{PhD}$ Thesis, University of Glasgow.

Pathon, S. (2009). Strong boards, CEO power and bank risk-taking. Journal of Banking and Finance, 33(7), 1340-1350. http://dx.doi.org/10.1016/j.jbankfin.2009.02.001

Raber, R. W. (2003). The role of good corporate governance in overseeing risk. Corporate Governance Advisor, 11(2), 11-16.

Solomon, J. F. (2007). Corporate Governance and Accountability (2nd ed.). New York: Wiley.

Subramaniam, N., McManus, L., \& Zhang, J. (2009). Corporate governance, firm characteristics and risk management committee formation in Australian companies. Managerial Auditing Journal, 24(4), 316-339. http://dx.doi.org/10.1108/02686900910948170

Sufian, F. (2010). The impact of risk on technical and scale efficiency; empirical evidence from the China banking sector. International Journal of Business performance management, 12(1), 37-71. http://dx.doi.org/10.1504/IJBPM.2010.036041

Tao, N. B., \& Hutchinson, M. (2012). Corporate governance and risk management committee: The role risk management and compensation committees. [Online] Available: http://ssrn.com/abstract=1979895

Walker, D. (2009). A review of corporate governance in UK banks and other financial industry entities: Final recommendations. [Online] Available: http://webarchive.nationalarchives.gov.uk/+/http:/www.hm-treasury.gov.uk/d/walker_review _261109.pdf

Xie, B., Davidson, W. N., \& Dadalt, P. J. (2003). Earnings management and corporate performance: the role of board and the audit committee. Journal of Corporate Finance, 9(3), 295-316. http://dx.doi.org/10.1016/S0929-1199(02)00006-8

Yatim, P. (2009). Audit committee characteristics and risk management of Malaysian listed Firms. Malaysian Accounting Review, 8(1), 19-36.

Yeh, Y-H., Chung, H., \& Liu, C-L. (2011). Committee independence and financial institution performance during the 2007-2008 credit crunch: Evidence from a multi-country study. 
Corporate Governance: An International Review, 19(5), 437-458. http://dx.doi.org/10.1111/j.1467-8683.2011.00884.x

Zulkifli, A., \& Abdul Samad, F. (2007). Corporate governance and performance of banking firms: Evidence from Asian emerging markets. In M. Hirschey, K. John, \& A. K. Makhija (Eds.), Issues in Corporate Governance and Finance (Advances in Financial Economics, Vol. 12, pp. 49-74). Emerald Group Publishing Limited. http://dx.doi.org/10.1016/S1569-3732(07)12003-X

\section{Copyright Disclaimer}

Copyright for this article is retained by the author(s), with first publication rights granted to the journal.

This is an open-access article distributed under the terms and conditions of the Creative Commons Attribution license (http://creativecommons.org/licenses/by/3.0/). 